\title{
Lipid Profile in a Tertiary Care Center
}

\author{
Pant $\mathrm{P},{ }^{1}$ Hamal PK, ${ }^{2}$ Gurung $D,{ }^{3}$ Upreti $K^{3}$ Subedi $K^{1}$
}

Department of Medicine, Kathmandu University Teaching Hospital, Dhulikhel, Nepal, 2Sukraraj Tropical and Infectious Disease Hospital, Ministry of Health and Population, Teku, Kathmandu, Nepal, 3xenoMED Foundation, Kathmandu, Nepal.

\section{ABSTRACT}

Introduction: Lipid profile is changing with changing developmental status and lifestyle in less developed countries and coronary artery disease risk factor is rising. The aim of the study is to find the lipid pattern in Department of Medicine in tertiary care hospital.

Methods: An observational prospective study was conducted in 408 subjects from January 2009 to February 2010. Study subjects were selected irrespective of co-morbid condition and coronary risk factors.

Results: The mean Triglycerides, Cholesterol, LDL, HDL were $138.3 \pm 78.3 \mathrm{mg} / \mathrm{dl}, 180.2 \pm 53.7 \mathrm{mg} / \mathrm{dl}$, $113.8 \pm 41.2 \mathrm{mg} / \mathrm{dl}, 40.1 \pm 10.1 \mathrm{mg} / \mathrm{dl}$ respectively. The Triglycerides $(>140 \mathrm{mg} / \mathrm{dl})$, Cholesterol $(>250$ $\mathrm{mg} / \mathrm{dl})$, LDL (>92 mg/dl), HDL (<45mg/dl) were $35.5 \%, 7.6 \%, 67.9 \%, 76 \%$ respectively.

Conclusions: Lipid profile is becoming atherogenic with high triglyceride, high LDL and low HDL being the most common abnormality. An epidemiological study is recommended to understand the true burden of the disease in the community.

Key Words: atherogenic, cholesterol, coronary artery disease, lipid profile, triglyceride

Correspondence:

Dr. Pankaj Pant

Department of Medicine, Kathmandu University Teaching

Hospital, Dhulikhel, Nepal.

Email: glargine78@gmail.com

Phone: 9851110939. 


\section{INTRODUCTION}

In Western countries, it has been shown that coronary heart disease (CHD) is related to high serum total cholesterol (TC) levels. In less developed continents such as Asia and Africa, serum lipid levels are low and CHD incidence is much lower as compared with Western countries. 1 With growing urbanization and industrialization in Asia, it has been shown that there is a concomitant rise in the level of serum TC and with it a rise in CHD. 1,2 Similar pattern of rise has also been observed in Southeast Asian region with a slow progress towards the suburban and rural area.2-4 Studies correlating with coronary risk factor and lipid profile in our setup are few with some study suggesting high total cholesterol and LDL as the common abnormality and some correlating with adverse cardiac outcome..$^{5-9}$ The objective of the study is finding the lipid pattern in Kathmandu University Teaching Hospital.

\section{METHODS}

A prospective observational study was carried out in Dhulikhel Hospital, Kavrepalanchowk district from January 2009 to March 2009. Ethical approval was taken from the hospital. The study subjects were taken based on convenient sampling method. All the study subjects in the Outpatient Department irrespective of their comorbid condition and risk factor predisposing to coronary artery disease were included in the study. Study subject who were terminally ill and admitted as inpatients were excluded. The lipid profile classification based on different level was classified as per the hospital guidelines. Data analysis were done using Microsoft excel 2007 and SPSS 11.9 Version.

Total of 408 cases were taken and their lipid profile studied. Majority of subject fell within $45-60$ years (35\%) age group followed by $30-45(25 \%)$ years. Male to Female ratio was 1.87:1.00 (Table1).

Table 1. Age and sex structure of the patients

\begin{tabular}{llll}
\hline Age & Male (\%) & Female (\%) & Total (\%) \\
\hline$\leq 15$ & $7(2.6)$ & - & $7(1.7)$ \\
$15-30$ & $26(9.8)$ & $18(12.7)$ & $44(10.8)$ \\
$30-45$ & $65(24.4)$ & $37(26.1)$ & $102(25.0)$ \\
$45-60$ & $96(36.1)$ & $48(33.8)$ & $144(35.3)$ \\
$60-75$ & $60(22.6)$ & $34(23.9)$ & $94(23.0)$ \\
375 & $12(4.5)$ & $5(3.5)$ & $17(4.2)$ \\
Total & $266(100)$ & $142(100)$ & $408(100)$ \\
\hline
\end{tabular}

Table 2. HDL level for males and females

\begin{tabular}{llll}
\hline HDL level & Male (\%) & Female (\%) & Total (\%) \\
\hline Below $45 \mathrm{mg} / \mathrm{dl}$ & $203(76.3)$ & $107(75.4)$ & $310(76.0)$ \\
$45-55 \mathrm{mg} / \mathrm{dl}$ & $48(18.0)$ & $25(17.6)$ & $73(17.9)$ \\
$55 \mathrm{mg} / \mathrm{dl}$ and above & $15(5.6)$ & $10(7.0)$ & $25(6.1)$ \\
Total & $\mathbf{2 6 6 ( 1 0 0 . 0 )}$ & $142(100.0)$ & $\mathbf{4 0 8 ( 1 0 0 . 0 )}$ \\
\hline
\end{tabular}

HDL level for male and female (below $45 \mathrm{mg} / \mathrm{dl}$ ) was recorded to be $203(76.3 \%)$ and $310(75.4 \%)$ respectively. Overall, 310 (76\%) were below $45 \mathrm{mg} / \mathrm{dl}$ (Table 2).

Table 3. LDL level for males and females

\begin{tabular}{llll}
\hline LDL level & Male (\%) & Female (\%) & Total (\%) \\
\hline$\leq 92$ & $86(32.3)$ & $45(31.7)$ & $131(32.1)$ \\
$92-150$ & $137(51.5)$ & $81(57.0)$ & $218(53.4)$ \\
s150 & $43(16.2)$ & $16(11.3)$ & $59(14.5)$ \\
Total & $266(100.0)$ & $142(100.0)$ & $408(100.0)$ \\
\hline
\end{tabular}

LDL level above $150 \mathrm{mg} / \mathrm{dl}$ were 59 (14.5\%), and 218 $(53.4 \%)$ were between the ranges of $92-159 \mathrm{mg} / \mathrm{dl}$ (Table 3). Values were comparative for both male and female.

Table 4. Triglycerides(TG) levels for males and females

\begin{tabular}{llll}
\hline TG level & Male (\%) & Female (\%) & Total (\%) \\
\hline$\leq 40 \mathrm{mg} / \mathrm{dl}$ & $3(1.1)$ & $1(0.7)$ & $4(1.0)$ \\
$40-140 \mathrm{mg} / \mathrm{dl}$ & $168(63.2)$ & $91(64.1)$ & $259(63.5)$ \\
$3140 \mathrm{mg} / \mathrm{dl}$ & $95(35.7)$ & $50(35.2)$ & $145(35.5)$ \\
Total & $\mathbf{2 6 6 ( 1 0 0 . 0 )}$ & $\mathbf{1 4 2 ( 1 0 0 . 0 )}$ & $\mathbf{4 0 8 ( 1 0 0 . 0 )}$ \\
\hline
\end{tabular}

TG values above $140 \mathrm{mg} / \mathrm{dl}$ were found to be 145 $(35.5 \%)$ and were comparative among male and female. Majority of people fell within $40-140 \mathrm{mg} / \mathrm{dl}$ (63.5\%) (Table 4).

Table 5. Levels of Cholesterol by sex

\begin{tabular}{llll}
\hline Cholesterol level & Male (\%) & Female (\%) & Total (\%) \\
\hline$\leq 150 \mathrm{mg} / \mathrm{dl}$ & $65(24.4)$ & $40(28.2)$ & $105(25.7)$ \\
$150-250 \mathrm{mg} / \mathrm{dl}$ & $178(66.9)$ & $94(66.2)$ & $272(66.7)$ \\
$3250 \mathrm{mg} / \mathrm{dl}$ & $23(8.6)$ & $8(5.6)$ & $31(7.6)$ \\
Total & $266(100.0)$ & $142(100.0)$ & $408(100.0)$ \\
\hline
\end{tabular}

Majority have cholesterol within the range of 50-150 $\mathrm{mg} / \mathrm{dl}(66.7 \%)$. Cholesterol values among male and female were comparative (Table 5). 


\begin{tabular}{llllll}
\hline Statistics & AGE & $\begin{array}{l}\text { HDL } \\
(\mathbf{m g} / \mathbf{d l})\end{array}$ & $\begin{array}{l}\text { (mg/dl) } \\
(\mathbf{m g} / \mathbf{d l})\end{array}$ & $\begin{array}{l}\text { (mg/dl) } \\
\text { (mglester }\end{array}$ \\
\hline Mean & 50.2 & 40.1 & 113.8 & 138.3 & 180.2 \\
Std. Deviation & 16.1 & 10.1 & 41.2 & 78.3 & 53.7 \\
Minimum Value & 1.0 & 1.0 & 32.0 & 10.0 & 24.0 \\
Maximum Value & 99.0 & 98.0 & 353.0 & 775.0 & 694.0 \\
Total count (N) & $\mathbf{4 0 8 . 0}$ & $\mathbf{4 0 8 . 0}$ & $\mathbf{4 0 8 . 0}$ & $\mathbf{4 0 8 . 0}$ & $\mathbf{4 0 8 . 0}$ \\
\hline
\end{tabular}

Mean age of presentation was $50.2 \pm 16.1$ years of age. TG values were $138 \pm 78.3 \mathrm{mg} / \mathrm{dl}$, LDL values were $113.8 \pm 41.2 \mathrm{mg} / \mathrm{dl}$ and $\mathrm{HDL}$ values were $40.1 \pm 10.1 \mathrm{mg} / \mathrm{dl}$ and cholesterol values were found to be $180 \pm 53.7 \mathrm{mg} / \mathrm{dl}$ (Table 6).

\section{DISCUSSIONS}

The study makes an effort to find the changing pattern of lipid profile and subsequent risk for developing coronary artery disease in our population. With growing population, changes in lifestyle and food habit especially in suburban and rural areas of the country, there is a potential threat of increasing risk factor for possible coronary artery disease. The study is conducted in Kathmandu University Teaching Hospital, located in Dhulikhel in Kavrepalanchowk district. The data although may not be as representative of the true rural population but shows the preponderance of a rural community. An epidemiological study with randomized population would have been more accurate, however we make an attempt to bring the changing pattern of coronary risk factor in the suburban population and hence the study is unique in itself.

The cholesterol level in our study is $272(66.7 \%)$ within the range of 150 to 250 i.e. above optimal and borderline high with the mean cholesterol being at $180 \pm 78.3$ showing much variation. Similar study conducted in Kathmandu valley in 2004 showed $30.25 \%$ had cholesterol high at similar ranges with more male preponderance. ${ }^{5}$ Another study done in National heart center in 2008 showed the cholesterol level to be $184 \pm 50.70 .6 \mathrm{~A}$ study done in India with lower socioeconomic strata showed the cholesterol level to be $37.4 \%$ in men and $43.1 \%$ in women.9 Another study done in Rajasthan India, urban as compared to rural men the prevalence of hypercholesterolemia $>200 \mathrm{mg} / \mathrm{dl}$ (28\% vs. $22 \%) .{ }^{10}$ Other rural India studies, showed the mean value of $220 \mathrm{mg} / \mathrm{dl}^{11}{ }^{11}$ The values in the study although shows high percentage is interpreted at the ranges of $150-250 \mathrm{mg} / \mathrm{dl}$ and can be compared to other studies. This only shows that there is definite rise in cholesterol level in rural setup as it was present in the urban areas three or four years back.
LDL level above $150 \mathrm{mg} / \mathrm{dl}$ were 59 (14.5\%), and 218 $(53.4 \%)$ were between the ranges of $92-159 \mathrm{mg} / \mathrm{dl}$ with a mean value $113 \pm 41.2 \mathrm{mg} / \mathrm{dl}$. Values were comparative for both male and female. In contrast, Kathmandu study showed above $160 \mathrm{mg} / \mathrm{dl}$ as $5 \%$ with mean of 84.97 $\mathrm{mg} / \mathrm{dl} .{ }^{5}$ National heart center showed mean of $111.9 \pm 42.0$ with $>190$ found in $5.8 \%$ of study subject. 6 The values are slightly higher as compared to the urban population hinting the possible increasing magnitude of high LDL.

HDL level for male and female (below $45 \mathrm{mg} / \mathrm{dl}$ ) was recorded to be $203(76.3 \%)$ and $310(75.4 \%)$ respectively. Overall, 310 (76\%) were below $45 \mathrm{mg} / \mathrm{dl}$. The mean value in our study was $40.1 \pm 10.1 \mathrm{mg} / \mathrm{dl}$. Other studied in urban setup showed mean value to be $49.08 \mathrm{mg} / \mathrm{dl} 5$ and $45.0 \pm 11.70 .6$ Similarly, values $<40 \mathrm{mg} / \mathrm{dl}$ were $23.30 \% 5$ and $40 \% 6$ were shown by the same studies. Although the ranges were different, one cannot rule out the decreasing HDL values.

In our study TG values above $140 \mathrm{mg} / \mathrm{dl}$ were found to be $145(35.5 \%)$ and were comparative among male and female. Majority of people fell within $40-140 \mathrm{mg} / \mathrm{dl}$ $(63.5 \%)$ with a mean value of $138.3 \pm 53.7 \mathrm{mg} / \mathrm{dl}$. A study in Kathmandu showed $31.5 \%$ had level $>200 \mathrm{mg} / \mathrm{dl}$ with a mean TG of $176.12 \mathrm{mg} / \mathrm{dl} 5$ and National heart center study shows $147.4 \pm 79.9 \mathrm{mg} / \mathrm{dl}$ with normal TG $(<150 \mathrm{mg} / \mathrm{dl}$ ) found in $61.5 \% .6$ The values are fairly comparable supporting the evidence that triglyceride level are on rise in these population.

Adverse dietary, anthropometric and metabolic factors are predictors of early and accelerated atherosclerosis in rural population of this part of world which is rising. ${ }^{12,13}$ Hypertension ,Smoking, abnormal lipid profile, obesity , glucose intolerance, genetic susceptibility and lack of physical activity has been cited as the possible reason for changing coronary risk factor in this part of world. ${ }^{1,2,12-17}$

Although, the study was unique on its way, it has its own limitation. Appropriate sampling and accurate sample size for a true epidemiological picture cannot be ruled out. Similarily, various comorbid conditions that play a role in changing the lipid profile are the other aspect to be considered. Hence, an epidemiological survey at a national level is recommended to get the true burden in urban, suburban and rural area of the country.

\section{CONCLUSIONS}

Lipid abnormalities are increasing in our population. High triglyceride, high LDL and low HDL are the most common abnormality. Atherogenic lipid profile among this population cannot be ruled out. 
A national level epidemiological study is recommended for comparative analysis of changing lifestyle and lipid

\section{REFERENCES}

1. Khoo KL, Tan H, Liew YM, Deslypere JP, Janus E. Lipids and coronary heart disease in Asia. Atherosclerosis. 2003 Jul;169(1):110.

2. Janus ED, Postiglione A, Singh RB, Lewis B. The modernization of Asia. Implications for coronary heart disease. Council on Arteriosclerosis of the International Society and Federation of Cardiology. Circulation. 1996 Dec 1;94(11):2671-3.

3. Chadha SL, Gopinath N, Shekhawat S. Urban-rural differences in the prevalence of coronary heart disease and its risk factors in Delhi. Bull World Health Organ. 1997;75(1):31-8.

4. Chaisiri K, Pongpaew P, Tungtrongchitr R, Phonrat B, Kulleap $\mathrm{S}$, Sutthiwong $\mathrm{P}$ et al. Nutritional status and serum lipids of a rural population in Northeast Thailand--an example of health transition. Int J Vitam Nutr Res. 1998;68(3):196-202.

5. Karki DB, Neopane A, Pradhan B, Magar A. Lipid levels in Nepalese population. Kathmandu Univ Med J (KUMJ). 2004 Oct-Dec;2(4):349-53.

6. Limbu YR, Rai SK, Ono K, Kurokawa M, Yanagida JI, Rai G et al. Lipid profile of adult Nepalese population. Nepal Med Coll J. 2008 Mar;10(1):4-7

7. Baral N, Jha P, Sridhar MG, Karki P, Sharma SK, Khambu B. Association of lipid profile and body mass index (bmi) in hypertensive patients of Eastern Nepal. JNMA J Nepal Med Assoc. 2006 Jul-Sep;45(163):306-9.

8. De Silva LD, Kumar A, Sathian B. The significance of lipid profile and positive troponin in predicting cardiac event. Kathmandu Univ Med J (KUMJ). 2009 Jul-Sep;7(27):263-7.

9. Gupta R, Gupta VP, Sarna M, Prakash H, Rastogi S, Gupta KD. Serial epidemiological surveys in an urban Indian population demonstrate increasing coronary risk factors among the lower socioeconomic strata. J Assoc Physicians India. 2003 May;51:4707. profile and its implication on coronary artery disease.

10. Gupta R, Prakash H, Kaul V. Cholesterol lipoproteins, triglycerides, rural-urban differences and prevalence of dyslipidaemia among males in Rajasthan. J Assoc Physician India. 1997 Apr;45(4):275-9.

11. Gupta R, Gupta HP, Kumar N, Joshi AK, Gupta VP. Lipoprotein lipids and the prevalence of hyperlipidaemia in rural India. J Cardiovasc Risk. 1994 Aug;1(2):179-84.

12. Misra A, Sharma R, Pandey RM, Khanna N. Adverse profile of dietary nutrients, anthropometry and lipids in urban slum dwellers of northern India. Eur J Clin Nutr. 2001 Sep;55(9):72734

13. Pradeepa R, Deepa R, Rani SS, Premalatha G, Saroja R, Mohan V. Socioeconomic status and dyslipidaemia in a South Indian population: the Chennai Urban Population Study (CUPS 11). Natl Med J India. 2003 Mar-Apr;16(2):73-8.

14. Mandal S, Saha JB, Mandal SC, Bhattacharya RN, Chakraborty M, Pal PP. Prevalence of ischemic heart disease among urban population of siliguri, west bengal. Indian J Community Med. 2009 Jan;34(1):19-23.

15. Chow CK, Naidu S, Raju K, Raju R, Joshi R, Sullivan D et al. Significant lipid, adiposity and metabolic abnormalities amongst 4535 Indians from a developing region of rural Andhra Pradesh. Atherosclerosis. 2008 Feb;196(2):943-52.

16. Begom R, Singh RB. Prevalence of coronary artery disease and its risk factors in the urban population of South and North India. Acta Cardiol. 1995;50(3):227-40.

17. Singh RB, Ghosh S, Niaz AM, Gupta S, Bishnoi I, Sharma JP et al. Epidemiologic study of diet and coronary risk factors in relation to central obesity and insulin levels in rural and urban populations of north India. Int J Cardiol. 1995 Jan 6;47(3):24555. 